\title{
Identification of catalase-like activity from Mycobacterium leprae and the relationship between catalase and isonicotinic acid hydrazide (INH)
}

\author{
TAE-JIN KANG, JI-CHANG YOU and GUE-TAE CHAE
}

Institute of Hansen's Disease, Department of Pathology, College of Medicine, Catholic University of Korea, Seoul, Republic of Korea

\begin{abstract}
As Mycobacterium leprae proliferate inside macrophages, it has been speculated that catalase encoded by $k a t G$ may protect the bacilli from deleterious effects of peroxide generated from the macrophage and may also play a crucial role in the survival of $M$. leprae in vivo. However, unlike that of M. tuberculosis, the katG of M. leprae has been reported to be a pseudogene, implicating that isoniazid, which is activated to a potent tuberculocidal agent by catalase, is unlikely to be of therapeutic benefit to leprosy patients. These results raise a question as to how $M$. leprae avoids $\mathrm{H}_{2} \mathrm{O}_{2}$-mediated killing inside macrophages. To understand the survival of $M$. leprae in macrophages, the present study attempted to detect catalase-like activity in $M$. leprae. Catalase-like activity was found in $M$. leprae cell lysate by the diaminobenzidine (DAB) staining method with non-denaturing polyacrylamide gel electrophoresis. An ammonium sulphate precipitation study revealed that the catalase-like activity was precipitable with $80 \%$ ammonium sulphate. The effect of isoniazid (INH) on M. leprae growth was also tested by RT-PCR and radiorespirometric assay to examine catalase-like activity in $M$. leprae, because INH was activated by catalase. It was found that the viability of $M$. leprae was decreased at a concentration of $20 \mu \mathrm{g} / \mathrm{ml}$ by radiorespirometric assay and it was inhibited at higher concentrations as determined by RT-PCR. These data suggest that a catalase-like activity other than that encoded by katG is present in M. leprae.
\end{abstract}

\section{Introduction}

In order to survive and proliferate, intracellular pathogens have defence mechanisms to deal with microbial killing mechanisms of host cells. Several mechanisms for resistance to intracellular killing have been proposed, including the scavenging of free radicals produced by mononuclear phagocytes. One protein with known free-radical scavenging activities, catalase (KatG), metabolises $\mathrm{H}_{2} \mathrm{O}_{2}$, a toxic oxygen metabolite [1]. Thus, the presence of catalase in mycobacteria probably enhances their pathogenicity, as it has been reported that Escherichia coli becomes resistant to killing by $\mathrm{H}_{2} \mathrm{O}_{2}$ by the expression of a catalase gene.

Received 23 Aug. 2000; revised version accepted 29 Dec. 2000.

Corresponding authors: Dr G-T. Chae (e-mail: guetae@cmc.cuk.ac.kr) and Dr J. C. You.
Isoniazid (isonicotinic acid hydrazide, INH) is one of the principal antituberculosis drugs. Catalase activates INH to a toxic oxidised derivative, which inhibits the biosynthesis of cell wall mycolic acids by linkage to other enzymes of the mycolic acids biosynthetic pathway [2].

Although several genes (inhA, katG and $\operatorname{oxy} R$ ) are involved in the mechanism of INH resistance in mycobacteria, the development of resistance in $M$. tuberculosis is often associated with a loss of catalaseperoxidase activity through mutations in the sequence of its kat $G$ gene $[3,4]$. To gain more insight into the mechanism of action of $\mathrm{INH}$, attempts were made to isolate and characterise catalase from $M$. leprae, as some workers have reported that the organism is susceptible to INH and the drug was used in the 1960s and 1970s to treat leprosy [5-7]. However, due to the unacceptable incidence of hepatic toxicity, INH was not recommended. Recently, INH was used with rifampicin in the treatment of borderline tuberculoid 
leprosy patients, resulting in the regression of nerve abscesses [8].

The katG gene of $M$. leprae is thought to be a pseudogene, an inactive, non-functional gene, unlike that of M. tuberculosis, because it contains multiple deletions. This implies that isoniazid is unlikely to be of therapeutic benefit to leprosy patients [9].

These contradictory observations raise a question about how $M$. leprae avoids $\mathrm{H}_{2} \mathrm{O}_{2}$-mediated killing; they suggest that there is a protein that confers protection against $\mathrm{H}_{2} \mathrm{O}_{2}$-mediated damage even in the absence of adequate catalase activity.

To investigate catalase-like activity in $M$. leprae, this study examined protein preparations by non-denaturing gel electrophoresis and diaminobenzidine (DAB) staining [10]. It also tested the effect of INH on M. leprae.

\section{Materials and methods} Cell lysate preparation, non-denaturing gel
electrophoresis and biochemical assay

Bacterial strains used for these studies were as follows: M. leprae Thai53, M. smegmatis $\mathrm{mc}^{2} 155$ and E. coli. $M$. leprae was obtained from infected nude mouse footpads by the methods described by Nakata et al. [11]. M. leprae bacilli from host tissues were purified at $4{ }^{\circ} \mathrm{C}$. Mouse footpads were minced and homogenised in phosphate-buffered saline (Sigma) and centrifuged at $100 \mathrm{~g}$ for $10 \mathrm{~min}$ to remove host cell components and the supernate was then centrifuged at $3500 \mathrm{~g}$ for $20 \mathrm{~min}$. The bacteria were enumerated by the procedure of Shepard and McRae [12]. M. smegmatis $\mathrm{mc}^{2} 155$ and E. coli were grown in M7H9 broth (Difco) containing Tween $8020 \%$ and LB broth, respectively. The bacteria were harvested and washed with PBS. The resulting pellet consisted of purified bacterial cells.

Bacteria were suspended in sonication buffer $(50 \mathrm{mM}$ Tris- $\mathrm{HCl}, 10 \mathrm{mM} \mathrm{MgCl}_{2}$, sodium azide $0.02 \%, \mathrm{pH} 7.4$ ) and treated ultrasonically for $10 \mathrm{~min}$ at $30 \mathrm{~W}$ for $E$. coli and M. smegmatis $\mathrm{mc}^{2} 155$, and for $45 \mathrm{~min}$ at 75 $\mathrm{W}$ for $M$. leprae with a Sonifier 250 (Branson Ultrasonic, USA) in an ice-water bath. The sonicated materials were centrifuged at $12000 \mathrm{~g}$ for $30 \mathrm{~min}$ and supernates were stored at $-20^{\circ} \mathrm{C}$ as cell lysates. Completeness of destruction was confirmed by microscopic examination of the pellet. Protein concentrations were estimated by the method of Bradford with bovine serum albumin fraction $\mathrm{V}$ as the standard.

Catalase activity was determined by monitoring the decomposition of $\mathrm{H}_{2} \mathrm{O}_{2}$ at $240 \mathrm{~nm}$ with a spectrophotometer (Hewlett Packard, Palo Alto, CA, USA) by a modification of the method described by Beers and Sizer [13]. Then $300 \mu \mathrm{l}$ of $50 \mathrm{mM}$ potassium phosphate buffer (Sigma) and $290 \mu \mathrm{l}$ of $\mathrm{H}_{2} \mathrm{O}_{2}$ solution (Sigma)
$0.036 \%$ were pipetted into a cuvette; $100 \mu \mathrm{l}$ of buffered bacterial lysates were added to the cuvette and mixed by pipetting. The time to required for the absorbance at $240 \mathrm{~nm}\left(\mathrm{~A}_{240}\right)$ to decrease from 0.45 to 0.40 absorbance units was recorded.

Catalase activity was also determined by the DAB staining method [10]. Non-denaturing gel electrophoresis of crude lysate $(40 \mu \mathrm{g})$ combined with loading buffer, containing neither SDS nor mercaptoethanol, was performed in a mini-gel system (Hoefer, Mighty Small II, San Francisco, CA, USA) at $150 \mathrm{~V}$. After completion of electrophoresis, the gel was stained in $3 \mathrm{ml}$ of diaminobenzidine (Sigma) $0.5 \mathrm{mg} / \mathrm{ml}$ and $3 \mathrm{ml}$ of horseradish peroxidase (Sigma) $50 \mu \mathrm{g} / \mathrm{ml}$ in $50 \mathrm{mM}$ potassium phosphate buffer $50 \mathrm{ml}, \mathrm{pH} 7.0$, at $23^{\circ} \mathrm{C}$, for $45 \mathrm{~min}$. The gel was then rinsed and soaked in $\mathrm{H}_{2} \mathrm{O}_{2}$ $0.006 \%$ in the phosphate buffer until staining was completed.

\section{Ammonium sulphate precipitation}

M. leprae lysate $(1 \mathrm{mg} / \mathrm{ml})$ was combined with $\left(\mathrm{NH}_{4}\right)_{2} \mathrm{SO}_{4} 0.113 \mathrm{~g}$ to make $1 \mathrm{ml}$ of $M$. leprae lysate (20\% saturation). When the ammonium sulphate (Sigma) was completely dissolved, the suspension was centrifuged at $10500 \mathrm{~g}$ for $20 \mathrm{~min}$ at $4^{\circ} \mathrm{C}$. Further amounts of $\left(\mathrm{NH}_{4}\right)_{2} \mathrm{SO}_{4}$ sulphate were added to the resulting supernates as follows: $0.121 \mathrm{~g}$ (40\% saturation), $0.130 \mathrm{~g}$ (60\% saturation), $0.140 \mathrm{~g}$ ( $80 \%$ saturation), $0.152 \mathrm{~g}$ (100\% saturation), respectively. The protein precipitate was collected by centrifugation $\left(10500 \mathrm{~g}, 20 \mathrm{~min}, 4^{\circ} \mathrm{C}\right)$ and resuspended with $50 \mathrm{~mm}$ phosphate buffer. Each of the fractions was used to determine catalase activity by the DAB staining method.

\section{Macrophage preparation, infection and drug treatment}

Peritoneal macrophages were harvested from BALB/c mice as described previously [14]. Briefly, cells were collected by lavage with $10 \mathrm{ml}$ of cold DPBS containing heparin (Sigma) $10 \mathrm{U} / \mathrm{ml}$, washed twice by centrifugation at $150 \mathrm{~g}$ for $10 \mathrm{~min}$ at $4^{\circ} \mathrm{C}$, and suspended in RPMI 1640 (Sigma) containing heatinactivated fetal bovine serum (Hyclone Lab, Logan, UT, USA) $10 \%$ and gentamicin (Sigma) $25 \mu \mathrm{g} / \mathrm{ml}$. Cell viability was consistently $>95 \%$ in the trypan blue (Sigma) exclusion test. Peritoneal macrophages were plated in six-well tissue-culture plates (Becton Dickenson Labware, Franklin Lakes, NJ, USA) at $2 \times 10^{6}$ cells/well and allowed to adhere for $2 \mathrm{~h}$ at $37^{\circ} \mathrm{C}$ in a humidified atmosphere containing $\mathrm{CO}_{2} 5 \%$ in air. Non-adherent cells were removed by washing with fresh medium and the plates were incubated overnight. In the morning, non-adherent cells were again removed by washing. The monolayers were overlaid with $6 \times 10^{7}$ bacilli of $M$. leprae in RPMI 1640 containing fetal bovine serum $10 \%$ adjusted to yield a bacter- 
ium:macrophage ratio of $30: 1$ and incubated at $37^{\circ} \mathrm{C}$. After $4 \mathrm{~h}$, the non-phagocytosed bacteria were removed by washing with warm DPBS. Cells were treated with RPMI 1640 containing serial dilutions of INH $\left(10-320 \mu \mathrm{g} / \mathrm{ml}\right.$; Sigma) and then incubated at $37^{\circ} \mathrm{C}$.

\section{RNA isolation}

INH-treated M. leprae in the macrophages were placed in Trizol reagent (Sigma) for RNA isolation. After macrophages infected with $M$. leprae were homogenised and lysed with $1 \mathrm{ml}$ of Trizol reagent, samples were transferred into $1.5-\mathrm{ml}$ sterilised microcentrifuge tubes. After extraction with chloroform (Sigma), RNA was precipitated with isopropanol (Merck, Damstadt, Germany) and resuspended with DEPC (Sigma)-treated water. To remove the contaminant DNA, samples were treated with DNaseI (Boehringer Mannheim, Germany) and RNAase inhibitor (Promega, Madison, WI, USA) for $1 \mathrm{~h}$ at $37^{\circ} \mathrm{C}$.

\section{cDNA synthesis}

cDNA was synthesised as described previously [15]. RNA was transcribed into cDNA by avian myeloblastosis virus reverse transcriptase (Promega) in a 20- $\mu$ l reaction volume containing $50 \mathrm{mM}$ Tris- $\mathrm{HCl}, 8 \mathrm{mM}$ $\mathrm{MgCl}_{2}, \quad 30 \mathrm{mM} \mathrm{KCl}, \quad 0.1 \mathrm{M}$ dithiothreitol, $10 \mathrm{mM}$ concentration of each deoxynucleoside triphosphate, $1 \mathrm{nM}$ random hexamers (Sigma) and $400 \mathrm{U}$ of RNAase inhibitor at $42^{\circ} \mathrm{C}$ for $1 \mathrm{~h}$. The mixture was then heated at $95^{\circ} \mathrm{C}$ to inactivate the enzymes, cooled and stored at $-20^{\circ} \mathrm{C}$.

\section{$R T-P C R$}

cDNA was subjected to 40 cycles of amplification by PCR with $M$. leprae-specific primers that amplify a $360-\mathrm{bp}$ segment of the $18-\mathrm{kDa}$ protein gene. PCR was performed in a total volume of $10 \mu \mathrm{l}$ of buffer obtained from Boehringer Mannheim (10 mM Tris- $\mathrm{HCl}, 1.5 \mathrm{mM}$ $\mathrm{MgCl}_{2}, 50 \mathrm{mM} \mathrm{KCl}$ ) containing $1.25 \mathrm{mM} \mathrm{dNTP}, 1 \mu \mathrm{M}$ of each primer, primer 1 (5'-ATTCGTCGTCGAGTTC GACCTTCCT-3'), primer 2 (5'-CTTAGCTTGTTGCG CAAACAACAGT-3'), template $1.5 \mu \mathrm{l}$ and AmpliTaq DNA polymerase $1 \mathrm{U}$. Negative controls, which contained all reaction components except the template, were included in all experiments to detect contamination. The cycling profile comprised denaturation at $94^{\circ} \mathrm{C}$ for $30 \mathrm{~s}$, annealing at $60^{\circ} \mathrm{C}$ for $30 \mathrm{~s}$ and extension at $72^{\circ} \mathrm{C}$ for $90 \mathrm{~s}$ for 40 cycles, followed by final extension at $72^{\circ} \mathrm{C}$ for $10 \mathrm{~min}$. Positive control DNA was processed under the same PCR conditions. PCR products were analysed by electrophoresis in an agarose $2 \%$ gel and ethidium bromide staining.

\section{Radiorespirometry}

A $0.3-\mathrm{ml}$ volume of $0.1 \mathrm{~N} \mathrm{NaOH}$ (Sigma) was added to INH-treated $M$. leprae and lysed macrophages infected by $M$. leprae. M. leprae suspensions were added to 6$\mathrm{ml}$ screw-cap vials containing 7H9 broth $1 \mathrm{ml}$ and [1${ }^{14} \mathrm{C}$ ]palmitic acid (Amersham) $1 \mu \mathrm{Ci}$. Non-infected macrophages and cell-free media were added to replicate vials as control. Culture vials, with caps loosened, were placed within wide-mouthed liquid scintillation vials containing a $2 \times 5-\mathrm{cm}$ strip of Whatman filter paper (Whatman International, Maidstone, Kent) to which $500 \mu \mathrm{l}$ of $2 \mathrm{~N} \mathrm{NaOH}$ had been added. The double-vial assemblies were then incubated for $24 \mathrm{~h}$ at $33^{\circ} \mathrm{C}$. The inner culture vials were removed, and $5 \mathrm{ml}$ of cocktail solution were added to the scintillation vials containing the filter papers. The counts/min (cpm) were determined in a liquid scintillation counter (Beckman LS-6000 Series, Palo Alto, CA, USA).

\section{Results}

\section{Catalase activity}

To examine catalase-like activity in $M$. leprae in vitro, cell lysate was obtained by sonication of $M$. leprae $\left(1 \times 10^{9}\right.$ bacilli $\left./ \mathrm{ml}\right)$. Spectrophotometry for catalase activity revealed enzyme activity in the three bacterial strains tested. Catalase-like activity was determined by monitoring the decomposition of $\mathrm{H}_{2} \mathrm{O}_{2}$ at $240 \mathrm{~nm}$ with a spectrophotometer with bovine liver catalase as control. Catalase activity was found in sonicated $E$. coli, M. smegmatis and $M$. leprae, although the catalase activity of $M$. leprae was weaker than that of the other bacteria (Table 1). DAB staining of nondenaturing gel electrophoresis for catalase activity also revealed catalase-like activity (Fig. 1). Catalase activity was visible almost instantly as an achromatic band against a brown background. This method showed one band with catalase activity in $M$. leprae similar to that in E. coli and M. smegmatis $\mathrm{mc}^{2} 155$. To determine

Table 1. Mobility and specific activity of catalase in bacterial lysates following non-denaturing polyacrylamide $7.5 \%$ gel electrophoresis and spectrophotometric assay

\begin{tabular}{lccc}
\hline Source & $\begin{array}{c}\text { Concentration } \\
(\mathrm{mg} / \mathrm{ml})\end{array}$ & $\begin{array}{c}\text { Specific activity } \\
\text { (unit/mg of protein) }\end{array}$ & $\begin{array}{c}\text { Mobility } \\
\text { (Rf) }\end{array}$ \\
\hline Bovine catalase & 10 & 20090 & 0.399 \\
Mouse catalase & 10 & 690 & 0.175 \\
E. coli lysate & 1.25 & 16.8 & 0.892 \\
M. smegmatis $\mathrm{mc}^{2} 155$ & 1.26 & 15.3 & 0.901 \\
M. leprae & 1.2 & 11 & 0.910 \\
\hline
\end{tabular}




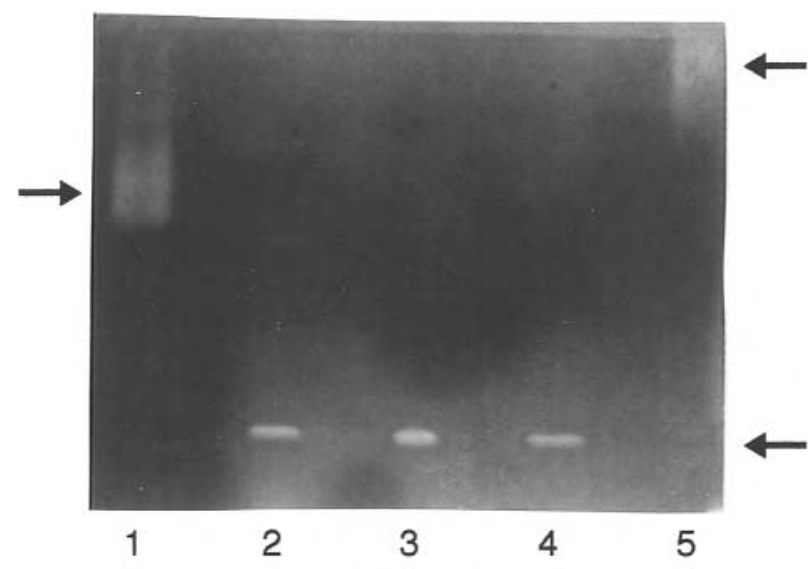

Fig. 1. Non-denaturing PAGE analysis of various bacterial cell lysates in non-denaturing polyacrylamide $7.5 \%$ gels stained by DAB methods. The band in M. leprae was believed not to be of host tissue origin because of the difference in location between $M$. leprae and mouse band. Lane 1, bovine catalase; 2, E. coli cell extract; 3, $M$. smegmatis cell extract; 4, M. leprae cell extract; 5, mouse liver catalase.

whether the band of $M$. leprae was derived from host cells, mouse liver catalase was tested as control. Catalase activity in $M$. leprae was believed not to be of host tissue origin, because of the difference in location between $M$. leprae and mouse catalase. The mobility of each of these bands and the corresponding total activity for each of the samples tested are listed in Table 1.

\section{Ammonium sulphate precipitation}

Bacterial extracts precipitated at different salt concentrations. Each precipitating extract was tested for catalase activity by the DAB staining method. The precipitating extract of $\left(\mathrm{NH}_{4}\right)_{2} \mathrm{SO}_{4} 80 \%$ in the $M$. leprae extract revealed one band with catalase activity (Fig. 2), in contrast to E. coli and M. smegmatis $\mathrm{mc}^{2} 155$ which had bands in the $60 \%$ precipitant (data not shown).

\section{Effects of INH on M. leprae analysed by RT-PCR and radiorespirometric assay}

The study also tested the effect of INH on the growth of $M$. leprae by RT-PCR and radiorespirometric assay, to examine the presence of catalase-like activity in $M$. leprae. AFB/methylene blue stain and DNA-PCR, respectively, were used to determine whether $M$. leprae used in these experiments was phagocytosed efficiently and consistently (Fig. 3a). It was found that the viability of $M$. leprae was decreased depending on drug concentrations and it was inhibited at INH $160 \mu \mathrm{g} / \mathrm{ml}$ as determined by RT-PCR (Fig. 3b), whereas in the radiorespirometric assay, M. leprae

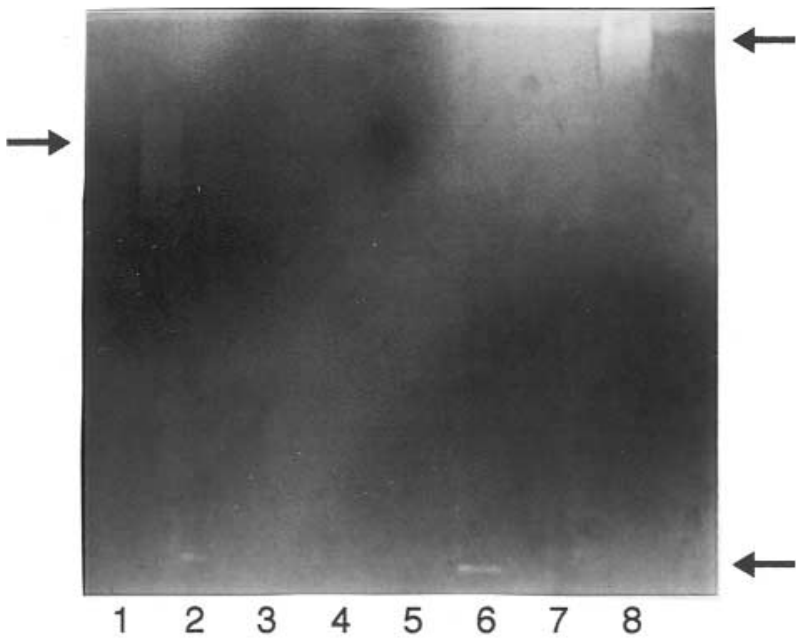

Fig. 2. Non-denaturing PAGE analysis of $\left(\mathrm{NH}_{4}\right)_{2} \mathrm{SO}_{4}$ fractionated $M$. leprae cell lysates. The precipitating extract of $80 \%\left(\mathrm{NH}_{4}\right)_{2} \mathrm{SO}_{4}$ in $M$. leprae extract revealed one band with catalase-like activity. Lane 1, bovine liver catalase; 2, M. leprae cell lysate; 3, 20\% fraction; 4, $40 \%$ fraction; 5, $60 \%$ fraction; $6,80 \%$ fraction; $7,100 \%$ fraction; 8, mouse liver catalase.

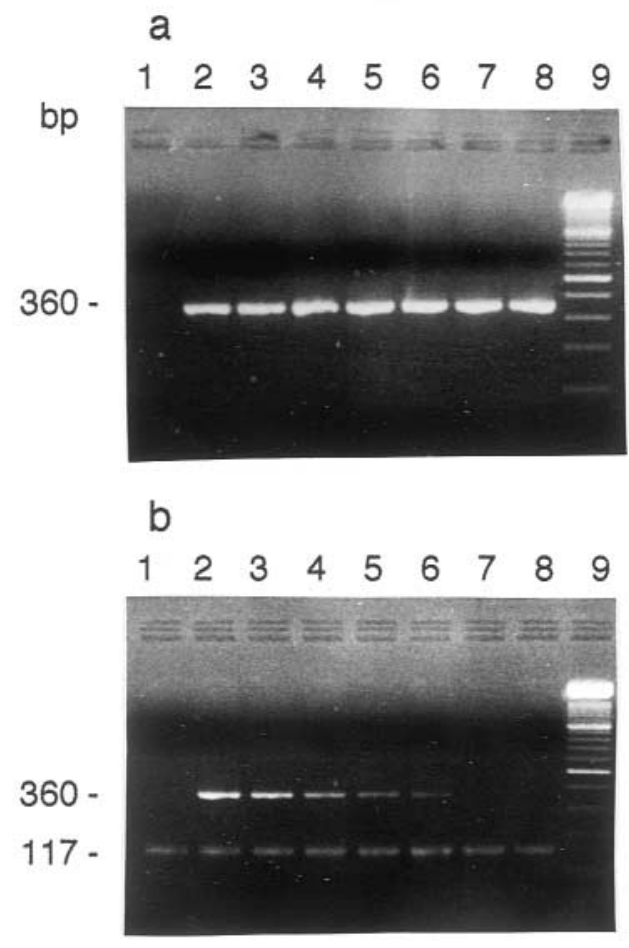

Fig. 3. (a) DNA-PCR analysis of the effect of INH on $M$. leprae. Analysis of PCR products from 40 cycles of PCR with primers for 360-bp product; $10 \mu 1$ of PCR product DNA were separated by electrophoresis through agarose $2 \%$ gel for $1 \mathrm{~h}$ at $80 \mathrm{~V}$ and stained with ethidium bromide. (b) Analysis of the effect of INH on M. leprae by RT-PCR: the 360-bp fragment of $M$. leprae DNA and 117 -bp fragment of pLLIII DNA as control were seen on agarose $2 \%$ gel and stained with ethidium bromide. Lane 1, $\mathrm{M} \Phi$ without $M$. leprae; 2, INH $0 \mu \mathrm{g} / \mathrm{ml} ; 3,10 \mu \mathrm{g} / \mathrm{ml}$; 4, $20 \mu \mathrm{g} / \mathrm{ml} ; \mathbf{5}, 40 \mu \mathrm{g} / \mathrm{ml} ; \mathbf{6}, 80 \mu \mathrm{g} / \mathrm{ml} ; \mathbf{7}, 160 \mu \mathrm{g} / \mathrm{ml} ; \mathbf{8}$, $320 \mu \mathrm{g} / \mathrm{ml} ; 9$, DNA ladder (100 bp). 
growth was inhibited at $20 \mu \mathrm{g} / \mathrm{ml}$ (Fig. 4). The result obtained by RT-PCR required higher concentration than that obtained by radiorespirometric assay. Although there is a difference between results obtained by the two methods, the viability of $M$. leprae was inhibited by $\mathrm{INH}$ as determined by both methods.

\section{Discussion}

Various mechanisms employed by mycobacteria to escape from the antimicrobial actions of mononuclear phagocytes have been reported. Possible mechanisms include inhibition of phagosome-lysosome fusion [16], inhibition of acidification of the phagosome [17] and scavenging or inhibition of bactericidal agent, such as reactive radicals. $M$. leprae is traditionally considered an obligate intracellular pathogen and proliferates within macrophages. The adaptation mechanisms that enable the human pathogens $M$. tuberculosis and $M$. leprae to thrive in the intracellular environment of susceptible mononuclear phagocytic cells are not completely understood, despite several recent advances. Of potential significance for the successful parasitism of host macrophages is the response of mycobacteria to oxidative stress, as reactive oxygen and nitrogen species are likely to be encountered during interactions with phagocytic cells. Previous studies have suggested that oxygen and reactive oxygen intermediates (ROI) produced by the host cells contribute to the control of mycobacterial growth and survival. ROIs include superoxide, $\mathrm{H}_{2} \mathrm{O}_{2}$ and hydroxyl radicals. Protection against ROIs is provided by antioxidant enzymes, such as superoxide dismutase, catalase and peroxidase. Superoxide dismutase was shown to be present in $M$. leprae, but attempts to detect catalase in $M$. leprae have so far been unsuccessful $[18,19]$. Catalase and peroxidase activities in $M$. leprae have been debated for a long time, since they were detected in humanderived M. leprae in 1967.

Recently, several workers have demonstrated that a $k a t G$ homologue of $E$. coli is also present in M. leprae and described nucleotide sequence analysis of the $M$. leprae DNA region homologous to those of other bacterial kat $G$ gene encoding a catalase. However, as discussed previously, the $k a t G$ gene of $M$. leprae is a pseudogene, which has probably been inactivated by multiple mutation events [11]. No characteristic of catalase-peroxidase activity could be detected in cellfree extracts of armadillo-derived $M$. leprae in biochemical studies by Wheeler and Gregory, who found weak catalase activity, which was believed to be of host tissue origin [19]. Lygren et al. also failed to find catalase activity in M. leprae [18]. In their report, unlike the other extracts, the M. leprae preparation had been exposed to irradiation to inactivate the bacilli. It is possible that this treatment may have inactivated a peroxidase-catalase activity. There are probably proteins and genes that confer protection against $\mathrm{H}_{2} \mathrm{O}_{2}$ mediated damage even in the loss of catalase activity, thus promoting survival of the $M$. leprae in the environment of the phagocytic oxidative burst. To survive during infection, isoniazid-resistant katG mutations have apparently compensated for the loss of KatG catalase-peroxidase activity by expression of another gene. INH-resistant, KatG-negative strains over-expressed alkyl hydroperoxidase (Ahp)C to a varying extent, whereas katG wild-type strains produced the $\mathrm{AhpC}$ protein at the low wild-type levels. The strict

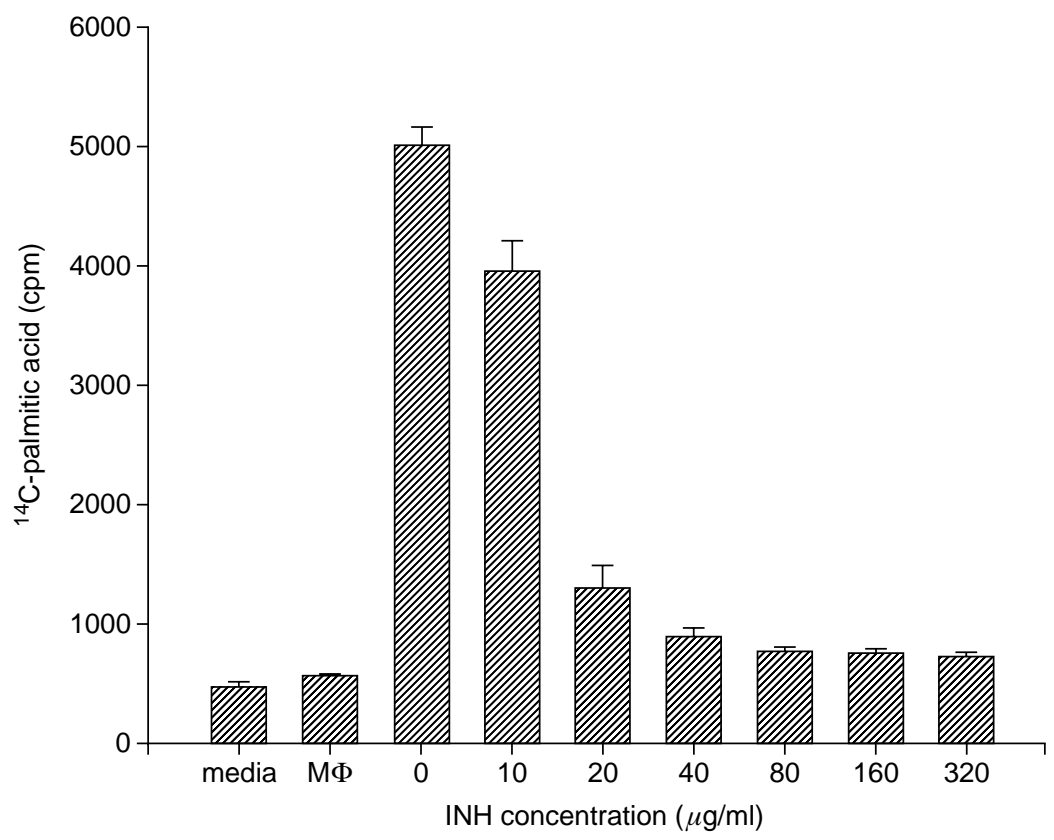

Fig. 4. The effect of INH on M. leprae as analysed by radiorespirometric assay. Radiorespirometric assay for M. leprae viability with the oxidation of $\left[1-\mathrm{C}^{14}\right]$ palmitic acid to $\mathrm{CO}_{2}$ by $M$. leprae as measured in Buddemeyer system. The viability of $M$. leprae was decreased at a concentration of $20 \mu \mathrm{g} / \mathrm{ml}$. 
correlation between loss of KatG function and overexpression of $\mathrm{AhpC}$ has also been noted recently by others [20,21]. AhpC is similar to a family of bacterial and eukaryotic antioxidant proteins with $\mathrm{Ahp}$ and thioredoxin-dependent peroxidase (Tpx) activities [22]. Although $a h p C$ can be induced by peroxide and involved in isoniazid resistance of the $M$. tuberculosis, it is not clear that $a h p C$ can be involved in protection of M. leprae from $\mathrm{H}_{2} \mathrm{O}_{2}$.

However, unlike the previous reports, the present study has shown a catalase-like activity in cell lysate of $M$. leprae and demonstrated the effect of INH on the growth of M. leprae. Furthermore, there is a report that isoniazid was used with rifampicin in the treatment of borderline tuberculoid leprosy patients with the result that nerve abscesses totally regressed [8]. These results suggest that a catalase-like activity is present in $M$. leprae and it was expected that Ahp and Tpx may play a key role in the survival of $M$. leprae in the presence of a high concentration of oxygen reactive intermediates produced by macrophages.

The DAB staining procedure was applied to polyacrylamide gel electrophoresis of crude cell lysates $[10,23]$. It is a simple and reliable method and successfully localises catalase in 200-0.2 units/band, so it was possible to detect $M$. leprae catalase activity that was weaker than that of other bacteria. There is another method available - a double-staining method that mixes DAB and ferricyanide to test catalase activity [24]. Mycobacteria produce two classes of catalase, the heat-labile T-catalase, which also has a peroxidase-like function, and the heat stable Mcatalase, which does not act as a peroxidase. It seems that the double-staining method is needed to distinguish between the two classes in the gels. It is believed that the double-staining procedure is very useful in characterising the catalase activity in M. leprae.

The present study used $\left(\mathrm{NH}_{4}\right)_{2} \mathrm{SO}_{4}$ precipitation to purify proteins that have catalase-like activity. The concentration of $80 \%\left(\mathrm{NH}_{4}\right)_{2} \mathrm{SO}_{4}$ precipitated a single band with catalase-like activity.

M. leprae has not only defied all attemps at cultivation in vitro, but also exhibits the longest generation time of all bacteria, requiring 13 days to double in experimentally infected mice. Because of that, it was difficult to isolate and purify the protein. To further identify and purify this activity, large quantities of protein from cell lysates had to be obtained so that the fraction that contained the enzymic activity in cell lysate could be purified and analysed

The mechanism of action of isoniazid against $M$. tuberculosis involves conversion of the inactive prodrug, INH, to an active form in a peroxidatic reaction catalysed by catalase, KatG, encoded by the kat $G$ gene. Isoniazid specifically targets a long-chain enoyl-acyl carrier protein reductase (InhA), an enzyme essential for mycolic acid biosynthesis in mycobacteria [2]. INH-resistant strains soon develop and this was often associated with concomitant loss of catalase activity and loss of virulence for guinea-pigs. Genetic confirmation that development of INH resistance is associated with loss of catalase came from experiments in which susceptibility to INH was restricted to INHresistant strains of $M$. smegmatis and $M$. tuberculosis by transforming them with a functional catalase gene (katG) [25].

The $18-\mathrm{kDa}$ PCR identified only the presence of $M$. leprae because it could not determine the viability of the organisms. Reverse transcription (RT)-PCR for $16 \mathrm{~S}$ rRNA of $M$. leprae in clinical specimens was developed recently [15]. This assay had 10 organisms as the lower limit of detection. The RT-PCR assay indicates the presence of viable organisms. The present study attemped to perform RT-PCR for mRNA for the 18$\mathrm{kDa}$ protein to ascertain the viability, and compared it with RT-PCR for 16S rRNA (data not shown). Amplified cDNA for the $18-\mathrm{kDa}$ protein was readily visible when $10^{2}$ organisms were present. RT-PCR for the $18-\mathrm{kDa}$ mRNA represented clearer changes of bands than those of the $18-\mathrm{kDa}$ PCR (data not shown). This means that the $18-\mathrm{kDa}$ mRNA is one of the wellconserved RNAs like 16S rRNA. RT-PCR was used to follow the efficacy of drug treatment. The viability of M. leprae was inhibited at INH $160 \mu \mathrm{g} / \mathrm{ml}$ in RT-PCR (Fig. 3b), growth of $M$. leprae was inhibited at $20 \mu \mathrm{g} / \mathrm{ml}$ in the radiorespirometric assay (Fig. 4).

To better understand the molecular basis of leprosy pathogenesis, the identification of many of the major components of mouse-derived $M$. leprae is required. This approach was undertaken in the belief that proteins expressed by the pathogen in vivo would reflect its expression within the host cell environment, thereby allowing a better understanding of the mycobacterium-host cell relationship. Future studies will undoubtedly include a careful analysis of candidate genes and proteins of $M$. leprae. The fraction that conferred the enzymic activity in this study will be further characterised.

This study was supported by a grant from the Catholic Medical Center Research Foundation made in the programme year of 1999.

\section{References}

1. Farr SB, Kogoma T. Oxidative stress responses in Escherichia coli and Salmonella typhimurium. Microbiol Rev 1991; 55: $561-585$.

2. Rozwarski DA, Grant GA, Barton DHR, Jacobs WR, Sacchettini JC. Modification of the NADH of the isoniazid target (inhA) from Mycobacterium tuberculosis. Science 1998; 279: 98-102.

3. Wilson TM, de Lisle GW, Collins DM. Effect of inhA and kat $G$ on isoniazid resistance and virulence of Mycobacterium bovis. Mol Microbiol 1995; 15: 1009-1015.

4. Zhang Y, Heym B, Allen B, Young D, Cole S. The catalase- 
peroxidase gene and isoniazid resistance of Mycobacterium tuberculosis. Nature 1992; 358: 591-593.

5. Freerksen E. The technique of evaluating anti-leprosy medications at the Forschungsinstitut Borstel. Lepr Rev 1975; 46 Suppl: $25-39$.

6. Freerksen E, Rosenfeld M. Leprosy eradication project of Malta. First published report after 5 years running. Chemotherapy 1977; 23: 356-386.

7. Kundu SK, Ghosh S, Hazra S, Chaudhury S. Multiple drug therapy - a comparative study with 2 tier and 3 tier combination of rifampicin, clofazimine, DDS, INAH and thiacetazone in lepromatous cases. Lepr India 1981; 53: 248-258.

8. Husain S, Mishira B, Malaviya GN. Rifampicin and isoniazid in the treatment of leprous nerve absesses. Acta Leprologica 1997; 10: $147-150$.

9. Eiglmeier K, Fsihi H, Heym B, Cole ST. On the catalaseperoxidase gene, katG, of Mycobacterium leprae and the implications for treatment of leprosy with isoniazid. FEMS Microbiol Lett 1997; 149: 273-278.

10. Gregory EM, Fridovich I. Visualization of catalase on acrylamide gels. Anal Biochem 1974; 58: 57-62.

11. Nakata N, Matsuoka M, Kashiwabara Y, Okada N, Sasakawa C. Nucleotide sequence of the Mycobacterium leprae kat $\mathrm{G}$ region. J Bacteriol 1997; 179: 3053-3057.

12. Shepard CC, McRae DH. A method for counting acid-bacilli. Int J Lepr 1968; 36: 78-82.

13. Beers RF, Sizer IW. A spectrophotometric method for measuring the breakdown of hydrogen peroxide by catalase. $J$ Biol Chem 1952; 195: 133-140.

14. Ramasesh N, Krabenbuhl JL, Hastings RC. In vitro effects of antimicrobial agents on Mycobacterium leprae in mouse peritoneal macrophages. Antimicrob Agents Chemother 1989; 33: $657-662$.

15. Kurabachew M, Wondium A, Ryon JJ. Reverse transcriptionPCR detection of Mycobacterium leprae in clinical specimens. $J$ Clin Microbiol 1998; 36: 1352-1356.
16. Clemens DL, Horwitz MA. Characterization of the Mycobacterium tuberculosis phagosome and evidence that phagosomal maturation is inhibited. J Exp Med 1995; 181: 257270 .

17. Sturgill-Koszycki S, Schlesinger PH, Chakraborty P et al. Lack of acidification in Mycobacterium phagosomes produced by exclusion of the vesicular proton-ATPase. Science 1994; 263: $678-681$.

18. Lygren ST, Closs O, Bercouvier H, Wayne LG. Catalases, peroxidases, and superoxide dismutases in Mycobacterium leprae and other mycobacteria studied by crossed immunoelectrophoresis and polyacrylamide gel electrophoresis. Infect Immun 1986; 54: 666-672.

19. Wheeler PR, Gregory D. Superoxide dismutase, peroxidatic activity and catalase in Mycobacterium leprae purified from armadillo liver. J Gen Microbiol 1980; 121: 457-464.

20. Kelley CL, Rouse DA, Sheldon L, Morris SL. Analysis of $a h p C$ gene mutations in isoniazid-resistant clinical isolates of Mycobacterium tuberculosis. Antimicrob Agents Chemother 1997; 41: 2057-2058.

21. Wilson TM, Collins DM. $a h p C$, a gene involved in isoniazid resistance of the Mycobacterium tuberculosis complex. Mol Microbiol 1996; 19: 1025-1034.

22. Cha M-K, Kim H-K, Kim I-H. Mutation and mutagenesis of thiol peroxidase of Escherichia coli and a new type of thiol peroxidase family. J Bacteriol 1996; 178: 5610-5614.

23. Roberts B, Hirst R. Identification and characterisation of a superoxide dismutase and catalase from Mycobacterium ulcerans. J Med Microbiol 1996; 45: 383-387.

24. Wayne LG, Diaz GA. A double staining method for differentiating between two classes of mycobacterial catalase in polyacrylamide electrophoresis gels. Anal Biochem 1986; 157: 89-92.

25. Zhang Y, Garbe T, Young D. Transformation with katG restores isoniazid-sensitivity in Mycobacterium tuberculosis isolates resistant to a range of drug concentrations. Mol Microbiol 1993; 8: 521-524. 